\title{
Česká katolická recepce pravoslavných filozofů a teologů ve 20. až 40. letech 20 . století
}

\section{A Czech Catholic View of Orthodox Philosophy and Theology from the 1920s to the 1940s}

Jiří Hanuš - Petr Husák / jirh1963@gmail.com - husak@phil.muni.cz Historický ústav, Filozofická fakulta, Masarykova univerzita, Brno

\begin{abstract}
This article examines the Catholic reception of works published in journals in the first half of the 20th century by Orthodox philosophers, theologians and writers, and explains their importance in Czech culture during this period.
\end{abstract}

\section{Key words}

Czech Catholicism in the first half of the 20th century, Orthodoxy, interpretation of works, cultural tradition 


\section{Úvod}

Ve většině děl věnovaných katolické kultuře v první polovině 20. století se setkáváme s tímto příběhem: katolíci jsou na přelomu století zdeptáni „spojením trůnu a oltáře“ $\mathrm{v}$ rámci rakouského státu, v tvưrčích oblastech činnosti vyprázdněni a marginalizováni, do značné míry odděleni od hlavních proudů národního hnutí a plní frustrací. Uvnitř komunity však žije velice čilá, i když malá kontrakultura, symbolizovaná staroříšským podivínským géniem Josefem Florianem, který - i když laik - dává kulturnímu katolicismu program. Dalo by se říci, že tento program tvoří idea „domácí univerzity“, založené na knižní produkci. Vznikem Československa se situace příliš nelepší, katolíci musí přestát mírnou formu republikánského kulturního boje. Naučí se ovšem žít v obtížných podmínkách nového režimu - alespoň tak náš příběh pokračuje - a ve dvacátých a třicátých letech nabudou ztracené sebevědomí a rozvinou nejen svůj potenciál ve směru staroříšském, ale i v dalších směrech, oblastech, včetně politických a kulturních. Už se nemusí stydět za své kulturní a umělecké výkony, a to jak ve smyslu individuálních děl (poezie, próza, výtvarné umění, překladatelství), tak ve směru institucionálního rozvoje. Zde je možné zmínit především význam časopisů, které si katolíci založili a vytvořili z nich platformu pro svou produkci - a eventuálně i pro uměleckou produkci vnitřně souznějících vzdělanců: filozofů, literátů, publicistů. Právě v těchto časopisech se můžeme setkat i s původními články a překlady, které se věnují vybraným ruským autorům. Příběh katolické kultury by končil „happy endem“, nebýt hnědého a posléze rudého teroru, které opět zatlačily katolicismus a jeho kulturní instituce do defenzívy, i když zcela nezničily hodnoty, na nichž byly vystavěny. I v rámci totalitní éry žili katolíci kulturou, kterou vybudovali v předválečných časech, a v rámci diaspory a ztížených možností existenčních se ji dokonce pokoušeli rozvíjet. Je však zapotřebí dodat, že tento příběh, jakkoli se už dnes podobá kánonu svého druhu, má několik slabých míst: např́íklad málo zdůrazňuje vliv prvorepublikové atmosféry a demokratického podhoubí, k němuž byli katolíci většinově velmi kritičtí, které jim však umožnilo mnoho jejich aktivit. To je ovšem námět na jinou studii.

\section{Dosavadní bádání}

Co se týče literatury k tématu, není možné nezmínit alespoň jednoho domácího autora, který svými publikacemi už vyvolal nejednu kontroverzní debatu. Máme na mysli Martina C. Putnu, literárního historika a kritika, překladatele, performera a zpěváka, který se ruským osobnostem věnoval jak ve své starší publikaci Rusko mimo Rusko (Petrov 1994, společně s Miluší Zadražilovou), tak ve své nejnovější práci Obrazy z kulturních dějin ruské religiozity (Vyšehrad 2015). Katolické recepci ruské kultury se však též jistým způsobem věnuje ve druhém díle své přehledové publikace s názvem Česká katolická literatura $v$ kontextech 1918-1945. ${ }^{1}$ Jakkoli není možné tyto práce opominout a jakkoli je možné

1 Putna, Martin: Česká katolická literatura 1918-1945. Praha 2010. 
přijmout mnoho Putnových originálních postřehů, přesto si však jeho texty zaslouží nejednu korekturu. Nejde ani tak o to, že zmíněné práce jsou nahuštěné informacemi, ale o to, že Putnova autorská metoda není historická, ale spíše literárně-srovnávací, a to v moderním smyslu slova. Nebojí se srovnání např́ič obdobími, styly a žánry, přičemž se odvažuje předkládat poměrně razantní a vypointované interpretace. $V$ každém případě i pro nás však představuje jakýsi odrazový můstek k našemu tématu, i když - máme-li se držet přirovnání - tento můstek je občas křehký a zaslouží kritické prověření.

Vedle prací Putnových ale nesmíme opominout ještě další příspěvek k tématu přítomnosti moderní ruské filosofické a zejména teologické tradice v západní Evropě s názvem Cesty pravoslavné teologie ve 20. století na Západ, který publikovali Ivana a Tim Noble, Kateřina Bauerová a Parush Parushev v roce 2012. ${ }^{2}$ Dané téma pojednávají komplexně, ale zároveň se snahou o poctivé zhodnocení teologického př́nosu klíčových osobností. Vzhledem k otázkám, které si chceme klást v tomto textu, se jako důležité jeví zejména ty pasáže, v nichž se autoři věnují ruské emigraci v Československu po roce 1918. Zabývají se Masarykovou Ruskou akcí, která vznikla v roce 1921 a jejímž cílem byla propagace stabilní a demokratické společnosti a poskytnutí přechodného azylu pro řadu ruských emigrantů - jednalo se o ruské občany v řádu tisíců lidí. Byli mezi nimi i významní náboženští myslitelé, jako např́íklad rodina Sergeje Bulgakova či Nikolaje Losského, ale i lidé bez vyznání nebo levicově a nenábožensky orientované osobnosti - asi k nejvýznamnějším postavám je možné zařadit učence Romana O. Jakobsona, který se načas uchytil na nově zřizené brněnské univerzitě. ${ }^{3}$ Autoři zmíněné publikace uvádějí, že Praha byla ve 20. letech nazývána „ruským Oxfordem“, ${ }^{4}$ i když připomínají, že to ruská emigrace neměla v Československu úplně jednoduché - akademických míst totiž nebylo nazbyt. Přesto vedle ruských škol vzniklo mnoho dalších institucí a čilých česko-ruských kontaktů.

Z dalších prací není možné nejmenovat obsáhlou historickou studii Pavla Marka a Volodymyra Burehy s názvem Pravoslavní v Československu v letech 1918-1953. ${ }^{5}$ I když autoři neopomíjejí význam ruské emigrace, jejich zájem se soustředuje především na domácí poměry, tj. na vznik a rozvoj pravoslavné církve (církví) v českých zemích, na Slovensku a na Podkarpatské Rusi. Podrobně vylíčili problémy s autokefalitou a jurisdikcí, budování církevních obcí a míst pro bohoslužby a také politické souvislosti vztahu pravoslavných církví a státu. Významnou součást publikace tvoří také portréty osobností pravoslavné církve i jejich osobních vztahů (arcibiskup Savvatij, biskup Dositej, biskup Gorazd, arcibiskup Sergij a další). Přínos knihy je možné vidět v pečlivém pramenném výzkumu a v rozkrytí vazeb jak mezi protagonisty náboženských obcí, tak mezi sledovanými zeměmi v rámci Československa. Uvedená publikace je pro naše téma důležitá,

2 Noble, Ivana - Bauerová, Kateřina - Noble, Tim - Parushev, Parush: Cesty pravoslavné teologie ve 20. století na Západ. Brno 2012.

3 Srov. např. Svatoň, Vladimír: Roman Jakobson v Brně a ve světě, viz: http://casopis.hostbrno.cz/archiv /2005/7-2005/roman-jakobson-v-brne-a-ve-svete (staženo 28. 1. 2016).

4 Noble, I. - Bauerová, K. - Noble, T. - Parushev, P.: Cesty pravoslavné teologie, s. 210.

5 Marek, Pavel-Bureha, Volodymyr: Pravoslavní v Československu v letech 1918-1953. Př́spěvek $k$ dějinám Pravoslavné církve v českých zemích, na Slovensku a na Podkarpatské Rusi. Brno 2008. 
nebot' ukazuje širší historické a společenské okolnosti vývoje, který je v případě pravoslaví poměrně komplikovaný.

\section{Historický kontext a unionistická tradice}

Než se pustíme do samotné analýzy katolické recepce ruských náboženských myslitelů, je nutné si uvědomit historický kontext, který ji provázel. Starší zájem o ruské reálie spatřujeme samozřejmě v celém 19. století v rámci českého „národního obrození“ s jeho ruskou, popřípadě slovanskou složkou, byl však výrazně aktualizován skutečností bolševické revoluce v roce 1917. V českém katolickém intelektuálním prostředí lze pozorovat zvýšenou snahu porozumět tomu, co se vlastně v Rusku stalo a jakou roli v tom sehrává pravoslavná víra. Nešlo však jen o otázku, před jakými výzvami stojí pravoslaví v sovětském Rusku, ale i o to, co nastalá situace může znamenat pro český národ po roce 1918. Doplňme, že s potřebou klást si podobné otázky se setkáme ještě jednou, a to $\mathrm{v}$ atmosféře předtuchy nového společenského i světového uspořádání po druhé světové válce. Jako vhodné časové vymezení, v němž byly zmíněné otázky vysloveny a promýšleny, lze proto zvolit období po roce 1918, tedy po vzniku samostatného Československa, do roku 1948, kdy došlo k radikálnímu omezení možnosti svobodného zhodnocení ruských filosoficko-teologických inspirací.

Jako konkrétní př́íklad zvýšeného zájmu o ruské pravoslavné reálie jmenujme nejprve revue Rozmach, již redigoval spisovatel Jaroslav Durych spolu s politizujícím publicistou Janem Scheinostem. Durych ve svém textu Posláni českého státu z roku 1923 jako jeden z klíčových úkolů československé vlády i českého národa označil tzv. unionismus. Využil tak starší tradice unionistických sjezdů, které se na Velehradě konaly již od roku 1907. (Celkem bylo uspořádáno sedm teologických kongresů: 1907, 1909, 1911, 1924, 1927, 1932, 1936). ${ }^{6}$ Vyzval nejprve k duchovní obrodě českého národa a k nasazení pro sjednocení církví, jež mělo být impulzem k obnovení víry v Rusku po revolučním rozvratu. Československo se mu zdálo být k tomuto úkolu vhodně disponováno svou geopolitickou polohou i „cyrilometodějskou“ minulostí. Pro Jaroslava Durycha je charakteristické, že si s praktickou proveditelností svých maximalistických plánů hlavu příliš nelámal, české společnosti proto vzkazuje: „Nebojte se být prvním národem světa, nejen prvním co do lesku a chlouby, ale i co do tíhy úkolů a závazků!"7 Tento akcent nebyl tak výjimečný, jak by se mohlo na první pohled zdát - na počátku první republiky se objevovalo mnoho podobných výzev, které prozrazovaly značné ambice zakladatelů a propagátorů nového státního útvaru - vedle náboženských vizí tu existovaly i vize „velké ř́íše“. Na druhou stranu je nutno dodat, že existence podobných nadějí na vzájemné sblížení byla vzhledem k př́ítomnosti ruské emigrace v Československu, včetně předních teologů a dalších učenců, přirozená. Přímo v revue Rozmach tuto naději se značným optimis-

6 Srov. Ambros, Pavel: Unionistické sjezdy na Velehradě 1907-2007. In: Encyklopedický slowník křest’anského východu. Eds. E. G. Farrugia; P. Ambros. Olomouc 2008, s. 925-927.

7 Durych, Jaroslav: Poslání českého státu. Rozmach 1, 1923, s. 10.

8 Srov. Kosatík, Pavel: České snění. Praha 2010, zvláště kapitoly Snění o moři a Snění o koloniích (s. 180nn). 
mem dále vyslovil například Josef Vašica, když napsal, že „...není pochyby, že i nynější nedobrovolná diaspora Rusủ po Evropě přispěje ke sblížení pravoslavných s katolíky a usnadní konečný triumf Kristovy vesměrné jednoty nad kmenovým a národnostním partikularismem. ${ }^{\text {"9 }}$ Unionistická aktivita se tedy měla nově zaměřit právě na příchozí věŕící a teology ruské pravoslavné církve.

Složitost reality vzájemných vztahů ale vyplula na povrch již v roce 1924 v souvislosti se čtvrtým unionistickým sjezdem. Durych v Rozmachu publikoval dopis Sergeje Bulgakova velehradskému sjezdu, pod nějž se podepsal např́iklad i Nikolaj Berdajev, Nikolaj Losskij či Grigorij Florovskij. Pravoslavní učenci odmítli svou účast a vznesli několik námitek do př́ípadné diskuse. Hlavní a vlastně tradiční námitku představovala kritika centralizace moci v rukou papeže..$^{10}$ Jaroslav Durych se v textu Odpovéd' Rusưm rozhodl zareagovat, když vyzval pravoslavnou stranu k odvaze přijmout pojetí církve ve formě, jejíž součástí je i absolutní věrnost papeži symbolizující věrnost samotnému Bohu. ${ }^{11}$ Přestože se zdá, že Durych i další čeští zájemci o sblížení s pravoslavím často hovořili odlišným jazykem než protistrana, upřímný zájem o inspirace v ruském prostředí, který byl postupně prohlubován a poněkud systematizován, jim upřít nelze. Soustř̌edil se kolem několika osobností, z nichž jsme vybrali pět nejvýznamnějších, a to jak vzhledem k závažnosti jejich díla, tak také s ohledem na šiři či míru, s jakou se čeští katoličtí intelektuálové ve svých periodikách těmito osobnostmi zabývali. Právě na příkladu těchto osobností se pokusíme ukázat strukturu i jednotlivá těžiště recepce jejich myšlení v českém prostředí.

\section{Petr Jakovlevič Čaadajev (1794-1856)}

První klíčovou osobnost, která ani v českém katolickém prostředí nemohla nerezonovat, představuje Petr Jakovlevič Čaadajev, který koncem 20. let 19. století sepsal několik filozofických listů o ruské kultuře, dějinách a náboženství. Přihlásil se k myšlence sjednocení se západní církví a označil ji dokonce za poslání ruského národa. Jeho list O filosofi dějin byl publikován v roce 1836 v časopise Těleskop, přirozeně vyvolal negativní reakci a nakonec vedl i k nucenému umístění samotného Čaadajeva do psychiatrické léčebny. V českém prostředí se jím zabýval už například Tomáš G. Masaryk, některé jeho listy vyšly česky ve Florianových Aršich a ve 30. letech o zpř́ístupnění jeho textů usiloval zejména kněz Josef Vašica (1884-1968). Přiznává, že se s touto osobností seznámil zprostředkovaně. Poprvé se o ní totiž dočetl v Masarykově práci Rusko a Evropa.${ }^{12} \mathrm{Jeho}$ snahu o zhodnocení Čaadajevova díla navzdory některým kritickým tónům Vašica oceňuje. Uvědomil si však, že český čtenář postrádá v prvé řadě překlady klíčových textů tohoto ruského filosofa. Navíc některé z nich byly objeveny či zpřístupněny právě až ve 30 . letech

9 Vašica, Josef: Slovanský unionismus. Rozmach 2, 1924, s. 212-213.

10 Bulgakov, Sergej: K velehradskému sjezdu. Rozmach 2, 1924, s. 265-266.

11 Durych, Jaroslav: Odpověd' Rusưm. Rozmach 2, 1924, s. 270.

12 Vašica, Josef: Úvodni poznámka. In: Čaadajev, Petr Jakovlevič: Filosofické listy. Praha 1947, s. 7. 
20. století. Vašica tedy v časopise $\check{R} a ́ d$ publikoval nejprve překlady listů $O$ filosofii dějin a $O$ protestantismu ${ }^{13}$ a později se dokonce podařilo vydat i další překlady knižně. ${ }^{14}$

Dle Vašici Čaadajeovy texty o poslání ruského národa významným způsobem aktualizovala právě bolševická revoluce. Čaadajevovy texty interpretoval jako vyslovení „kruté pravdy“ o vlastním národě odhalením původu zla v Rusku, které mělo spočívat v tom, že „...přijalo křestanství z Byzance a spolu s ní se pak octlo v rozporu s ostatní velkou obcí národů sjednocených v středověké Církvi. "15 Vašica přirozeně nemohl neocenit Čaadajevovo pozitivní hodnocení papežství jako symbolu jednoty církve, touhu po sjednocení i kritiku protestantismu. Inspirací mu však byl i svým odhodláním vyrovnat se s minulostí vlastního národa: „Čaadajev nás burcuje k tomu, abychom se čestně a rozumně vyrovnali se svou minulostí, se svými dějinami. V jeho Obraně čteme tato zmužilá slova: ,Nezvykl jsem si milovat svou vlast se sklopenýma očima, s ohnutou šíjí, s ústy na zámek. Myslím, že možno být užitečným své vlasti jen pod podmínkou, že do všeho jasně vidíme; podle mého mínění čas zaslepené lásky minul, dnes jsme povinni své vlasti především pravdou. 'Pravda - to je také jediný pevný základ národní prosperity a bezpečná záruka do budoucna." 16

Postava Petra J. Čaadajeva byla tedy díky českým katolíkům představena ve značné šíri, i když se pozornost často stáčela na jeho konverzi a blízkost západní církvi a papeži.

\section{Nikolaj Vasiljevič Gogol (1809-1852)}

Tento ruský spisovatel nebyl jen autorem beletristických děl s velikým dramatickým potenciálem a satirickými akcenty, které jsou dodnes na repertoáru velkých světových scén (Revizor, Hráči, Mrtvé duše), ale také hluboce věřícím pravoslavným křestanem, který svoji víru výslovně vyjádřil v drobném náboženském díle Rozjimáni o božské liturgii z roku 1845, jež napsal v Paříži. Tento autor se začal věnovat náboženským záležitostem v pozdějších etapách svého života, v nichž trpěl depresemi a dokonce ničil svá díla, která napsal v dřívějším životním období. Není překvapující, že právě ortodoxní vírou ovlivněné dílo zaujalo i české autory natolik, že je překládali a interpretovali. Asi nejvýznamnější počin v tomto směru představuje uveřejnění ukázek z Rozjimáni a posléze jeho celý překlad, který pořídil Josef Vašica a vydal ve Staré Říši pod názvem Rozjimáni o mši svatév roce 1936. ${ }^{17}$ Ukázky z Gogola byly otištěny např́íklad i v dominikánském časopise Na hlubinu ve druhé polovině 20. let - šlo o pasáže, které odpovídaly zaměření

13 Čaadajev, Petr J.: List o filosofii dějiny. ̌̌ád 2, 1934, s. 221-235; Čaadajev, Petr J.: O protestantismu. ̌̌ád 2, 1934, s. 285-289.

14 Čaadajev, Petr J.: Filosofické listy. Přeložil Josef Vašica. Praha 1947.

15 Vašica, Josef: Předchůdce Solověvữv. Vyšehrad 1, 1946, č. 25-27, s. 30.

16 Vašica, Josef: Několik slov o Čaadajevovi. Vyšehrad 2, 1947, s. 253.

17 Vašica nebyl první, který Gogolovy náboženské texty překládal. České prvenství bývá připisováno Quidonu Hodurovi, který tohoto ruského spisovatele překládal pro Ottovu ruskou knihovnu. Vašicovy překlady jsou kvalitní mj. z toho důvodu, že překladatel přihlížel k řeckému textu východní liturgie. 
časopisu. ${ }^{18} \mathrm{~V}$ roce 1928 zde vyšly např́íklad poetické partie z Gogola věnované modlitbě Otčenáš: „Tato modlitba obsáhla vše a v ní zahrnuto vše, co nám třeba. Prosbou: posvět' se jméno Tvé, prosíme za to první, zač máme především prositi: kde se posvěcuje jméno Boží, tam je všem dobře, tam totiž všichni žijí v lásce, nebot’ jen láskou se posvěcuje jméno Boží. Slovy: prijd'královstui Tvé, svolává se království spravedlnosti na zemi, nebot' bez př́íchodu Božího nebylo by spravedlnosti: nebot'Bůh jest spravedlnost. K slovům: bud'vưle Tvá, přivádí člověka víra i rozum: čí zajisté vůle může býti krásnější než vưle Boží? Kdo zná lépe než sám Tvưrce, co je potřebí jeho tvoru? Komu bychom se svěřili, ne-li Tomu, který všecek jest blahodějné dobro a dokonalost? Slovy: chléb náš vezdejši dej nám dnes, prosíme za vše, co potřeba k našemu dennímu životu, chlebem pak naším jest moudrost Boží, jest sám Kristus. On sám řekl: Já jsem chléb, a kdo Mne jí, nezemře (Jan VI. 50). Slovem odpust' nám naše dluhy, prosíme, aby z nás byly sňaty všechny naše smrtelné hříchy, nás tížící, - prosíme, aby nám bylo odpuštěno vše to, čím jsme se zadlužili samému Tvůrci v podobě svých bratří, nebot' On každý den a každý okamžik k nám napřahá v jejich podobě svou ruku, hlasem rozdírajícím duši žádaje o milosrdenství a slitování. Slovem: neuvod'nás v pokušení, prosíme, abychom byli zbaveni všeho, co jitří našeho ducha a odnímá nám duševní klid. Slovem: ale zbav nás od zlého, prosíme o nebeskou radost: nebot' sotvaže odstoupí od nás Zlý, tu ihned vchází radost do naší duše, a my jsme již na zemi jako na nebi." 19

Josef Vašica v poznámkách k vydání Gogolovy knihy připomíná jeho psychické potíže, rozebírá překládané dílo a poukazuje mimo jiné i na autorovu lásku k městu Rímu, kde se setkával také s ruskými a polskými katolíky. Z toho důvodu Vašica lituje, že Gogol na rozdíl od Čaadajeva nedokázal postřehnout naléhavost obnovy „církevní jednoty a církevní autority v tom smyslu, jak ji vyjadřuje katolictví a papežství", přestože je dle Vašici toto sjednocení „nezbytnou podmínkou křestanské kultury na Rusi. “20 Mimochodem totéž podtrhl i tehdejší recenzent Rozjimání Josef Beran, budoucí arcibiskup pražský, v Časopisu katolického duchovenstva v roce 1937, kde toto dílo doporučuje ke čtení široké veřejnosti. ${ }^{21} \mathrm{Z}$ toho je zřejmé, že sice katolíci tehdejší doby stále vnímali pravoslaví na jedné straně jako cosi defektního, na druhé straně ale uznávali hodnoty vzniklé na jeho půdě, v tomto případě liturgické. Četba Gogolových liturgických meditací je totiž na více místech, tedy nikoli pouze ve Vašicově doslovu k překladu Rozjimání, prezentována jako důležitý nástroj nejen k snazšímu pochopení povahy pravoslavné liturgie, ale také k prohloubení prožívání a chápání bohoslužebného slavení u samotných katolíků. Oceňována je především autorova schopnost intimního vhledu do krás liturgie a umění

18 Na Hlubinu, revue pro duchovní život 3, 1928, č. 2. Dostupné $i$ na http://revue.theofil.cz/revue-clanek. php?clanek=1205 (staženo 28. 1. 2016).

19 Gogol, Nikolaj Vasiljevič: Rozjimání o mši svaté. Přeložil Josef Vašica. Stará Ř́̌še 1936, s. 83-84.

20 Vašica, Josef: Poznámka literárněhistorická. In: Gogol, Nikolaj Vasiljevič: Rozjímání o mši svaté. Stará Ř́uše 1936, s. 112.

21 Beran, Josef: N. V. Gogol: Rozjímání o mši svaté. Z ruštiny přeložil prof. Dr. Josef Vašica. Časopis katolického duchovenstva 78, 1937, č. 1, s. 99-100. Dostupné na: http://www.depositum.cz/knihovny/ckd/tiskclanek. php?id=c_24652_(staženo 22. 1. 2016). 
vystihnout její - poeticky řečeno - pokrevní příbuzenství s různorodými a často obtížnými peripetiemi lidského života. ${ }^{22}$

\section{Fjodor Michajlovič Dostojevskij (1821-1881)}

Zájem o mohutné dílo Fjodara Michajloviče Dostojevského měl poněkud odlišné motivy než v případě Čaadajovově. Dostojevskij totiž k zastáncům sblížení se západním katolictvím rozhodně nepatřil, jeho umělecký i duchovní přínos je však natolik závažný, že nemohl zůstat bez pokusu o hlubší porozumění. V českém katolickém prostředí se mu ve svých textech věnuje více autorů, pokud bychom ale ve sledovaném období měli vybrat alespoň jednoho, byl by to Alois Lang (1869-1957). Tento katolický kněz, překladatel a znalec křestanské mystické literatury a mimo jiné i spolupracovník Josefa Floriana se od 30. let ve svých esejích pokoušel systematicky promýšlet Dostojevského dílo. Vycházely nejprve v časopise Akord a později vyšly i knižně. ${ }^{23}$

Skrze Dostojevského románové postavy a s tím související analýzu ruské duše se Lang snaží pochopit dění v sovětském Rusku. Dostojevského v této souvislosti vnímá jako geniálního vizionáře, který vlastně sepsal budoucí apokalypsu, která postihla ruský národ bolševickou revolucí. Zároveň oceňuje jeho kritiku ruského nihilismu i západního ateismu a schopnost vystihnout snadnost, s jakou některé západní myšlenky pronikly do ruské mentality: „...žasneme nad silou jasnožrivosti, jíž pronikal až k základům ruské duše, ukazuje, do jaké míry ona dovede nejen uvěřiti nejnesmyslnějším myšlenkám západních filozofů, nýbrž z nich ihned vyvodí nejkrajnější důsledky. " dovedně vystihl i „zradu“ socialismu, usilujícího o vytvoření pozemského „božího království“, které je v prvé řadě tajemstvím víry. A tajemstvím víry se „...daří jedině na půdě církve; přesazená mimo církevní obvod bud' docela zakrňují, nebo se strašně zvrhají." ${ }^{25}$

Jednu věc však Lang Dostojevskému a potažmo i ruskému pravoslaví vytýká, totiž spojení se světskou mocí a ztotožnění ideálu jedné, pravé církve s ruským pravoslavným národem. Dostojevskému je sice státní moc ve vztahu k církvi sekundární, má být církví zcela prostoupena, Rus jako takovou si ale v konečném důsledku nedovede představit jinak než jako mocný a silný stát se svrchovaností jak nad případně osvobozeným Cařihradem, tak nad celým pravoslavným křestanstvem. V tomto smyslu je dítětem ruské tradice, jejíž součástí je dle Langa i církev jako útočiště často těžce zkoušeného národa, která však vychovávala ruský lid nejen k neobyčejné náboženské vroucnosti, ale také $\mathrm{k}$ otrocké poddajnosti vưči panovníkům. ${ }^{26}$

Čeští katolíci si nemohli nevšimnout toho, jak kriticky se Dostojevskij staví k římskému katolicismu (Legenda o Antikristu) a k jeho historii a tradicím. Na druhé straně to

$22 \mathrm{D}[$ urych], J[aroslav].: N. V. Gogol: Rozjímání o mši svaté. Z ruštiny přeložil Dr. Josef Vašica. Ř́a 3, 1936, s. 458459.

Lang, Alois: F. M. Dostojevskij. Kř̌žová cesta náboženského myslitele. Praha 1947.

24 Lang, Alois: Dostojevského Běsové. Akord 3, 1930, s. 73.

25 Lang, Alois: Dostojevskij a pravoslavná církev. Akord 3, 1930, s. 240-241.

26 Lang, Alois: Závěrečná synthesa Dostojevského. Akord 3, s. 351. 
byli schopni tomuto ruskému velikánovi do jisté míry tolerovat - věděli totiž, že se ho mohou dovolávat při své vlastní kritice protikatolických ideologií tehdejší doby.

\section{Vladimir Sergejevič Solovjov (1853-1900)}

Výjimečné postavení mezi ruskými náboženskými mysliteli nepochybně zastával Vladimir Solovjov, který se nejexplicitněji přihlásil k myšlence sjednocení s katolickou církví. V roce 1896 se rozhodl jako pravoslavný křestån přijmout za nejvyšší autoritu v církvi římského biskupa jakožto nástupce sv. Petra. Svým sofiologicky laděným dílem navíc ovlivnil další generace ruských teologů a myslitelů jako např́íklad Sergeje Bulgakova nebo Nikolaje Berdajeva. Základem jeho myšlení se staly dva pojmy: „bohočlověčenství“, tedy spolupráce člověka a Boha na stvořitelském díle, a „všejednota“ jako princip mystického sjednocení nejen v rovině církevní, ale i v rovině obecně lidské. Recepci jeho díla v českém prostředí můžeme sledovat již od konce 19. století, at’už šlo o překladatelství či snahu o analýzu jeho děl. Několik překladů vyšlo i v renomovaných nakladatelstvích Ladislava Kuncíře či v dominikánském Krystalu ve 20. a 30. letech. ${ }^{27}$ Jisté vyvrcholení zájmu o tohoto myslitele v katolickém prostředí před rokem 1948 představuje časopis Vyšehrad, konkrétně číslo 25-27 z roku 1946, jež vyšlo u př́íležitosti padesátého výročí Solovjovova „katolického“ vyznání.

Z celého čísla je možné vybrat alespoň dva texty. První je překlad shrnutí Solovjovova pojetí „ruské myšlenky“ s názvem Pravé pravoslavi ruského lidu a nepravé pravoslaví protikatolických bohoslovců, již uveřejnil v knize Rusko a univerzálni církev (1889). ${ }^{28} \mathrm{~V}$ tomto textu odmítl pokládat za základ ruského pravoslaví i národní identity „pouhou“ kritiku papežství, Filioque a dogmatu o neposkvrněném početí: „Dosad’te tyto již uvedené rozdíly místo neurčitého výrazu ,pravoslaví‘ a řekněte otevřeně, že náboženská idea Ruska pozůstává v neuznání ,Filioque, neposkvrněného Početí a prvenství římského biskupa‘. [...] Celé vaše ,pravoslaví‘ a celá vaše ,ruská idea není tedy v podstatě nic jiného než národní protest proti universální moci papežově. "29 Takové pravoslaví je dle něj partikulární a vlastně lživé. Ruský lid však dovedl setrvat u autentického jádra, jež náleží univerzální církvi. Základem ruské národní myšlenky proto musí být úsilí o sjednocení s katolickou církví: „Proti nejistým míněním slovo Petrovo staví pevnost a jednotu pravé víry; proti úzkoprsosti národních domněnek o Mesiáši [...] staví mesiánskou ideu v její absolutní a všeobecné podobě. [...] Jen po vyznání Petrově se mesiánská myšlenka vymaňuje ze všeho národnostního živlu a po prvé bere na sebe konečnou všeobecnou formu. “30

27 Např́íklad: Solovjov, Vladimir S.: Duchovni základy života. Přeložila Anna Tesková. Družstvo přátel Studia, Praha 1923; Týž: Legenda o Antikristu. Fantastická povidka, již vložil Vl. Solovjev do své posledni práce Tři rozhovory. Přeložila Anna Tesková. Krystal, Olomouc 1936; Týž.: Židouství a křsst'anská otázka. Krystal, Olomouc 1939.

28 Solovjov, Vladimir S.: Pravé pravoslaví ruského lidu a nepravé pravoslaví protikatolických bohoslovců. Vyšehrad 1, 1946, č. 25-27, s. 24-25.

29 Tamtéž, s. 25.

30 Solovjov, Vladimir S.: Skála Církve. Vyšehrad 1, 1946, č. 25-27, s. 19-20. 
Druhý text nás přivádí ke skutečnosti, která je v souvislosti se Solovjovem i se snahou o poznávání východního křestannství rovněž velmi důležitá. Solovjovův způsob uvažovaní i psaní totiž představoval hozenou rukavici katolickým teologům formovaným v té době neoscholastickou naukou. V témže čísle Vyšehradu se pokusil tuto rukavici zvednout například mladý teolog Alexander Heidler (1916-1980). V konfrontaci s všeobecným pocitem tragiky a absurdity lidské existence po zkušenosti druhé světové války si uvědomil, že v porovnání s „kérygmatickým“, mystickým pojetím hlásání evangelia u Solovjova se jeví scholastický přístup jako poněkud schematický: „Naše bohoslovné vzdělání je při vší hloubce a přesnosti jaksi suché, příliš abstraktní a neživotné. Všímáme si drobnohledných podrobností [...] a najednou nám trochu uniká celek se svou nesmírně životnou souvislostí. A přece právě v ní lze spatřovat jakýsi morální zázrak, který by pro mnohého dnešního člověka byl možná větším dokladem věrohodnosti než zázraky hmotné. Ale my často nedovedeme vybudovati most mezi svou bohoslovnou erudicí a potřebami křestanů ve světě. Někdy je pak častujeme jenom velmi fádními odvary křestanské nauky. “31 Samožrejmě vidí i pozitivní přínosy scholastiky a kritizuje některé aspekty Solovjovova myšlení, podstatnější je ale to, že nabízí v prvé řadě zajímavé svědectví o určité relativizaci dosud výsadního postavení scholastického přístupu v katolické teologii, která se výrazněji projeví až po II. vatikánském koncilu. Vzhledem k tématu tohoto př́íspěvku je klíčová právě ta skutečnost, že k podobným posunům přispívala i recepce ruských náboženských myslitelů.

\section{Nikolaj Alexandrovič Berd'ajev (1874-1948)}

Poslední z pěti osobností, které chceme v našem příspěvku zmínit, je Nikolaj Berd’ajev. V mnohém navázal na svého inspirátora Vladimira Solovjova, jehož nauku o „bohočlověčenství “se pokoušel dále rozvíjet. Rovněž projevil osobní touhu po sjednocení západního i východního křestanství, jež byla navíc umocňována osobními kontakty se západními filozofy a teology po roce 1922, kdy byl nucen za pohnutých okolností opustit svou vlast. Nakonec svůj nový domov našel v Paříži, zcela cizí mu však nebylo ani české prostředí, kde se například v roce 1923 zúčastnil přerovského sjezdu exilového Ruského křest'anského studentského hnuti. ${ }^{32}$ Soustavnějšího překladu jeho děl se však čeští čtenáři před rokem 1948 nedočkali. Přesto se podařilo v několika periodikách publikovat v češtině alespoň některé jeho stati.

Zvláštnímu zájmu se těšily zejména Berdajevovy úvahy nad ruskou revolucí a porevolučním vývojem. Například v již zmíněném časopise Akord, na jehož redakci se mimochodem opět podílel Jaroslav Durych, byl publikován Berdajevův text Úvahy o ruské revoluci. ${ }^{33}$ Pro katolické prostředí byl uchopitelný a zároveň zajímavý především ze dvou důvodů: častými odkazy na západní katolické umělce či myslitele (Joseph de Maistre,

31 Heidler, Alexander: Bohosloví scholastické a kérygmatické. Vyšehrad 1, 1946, č. 25-27, s. 47.

32 Noble, Ivana - Bauerová, Kateřina - Noble, Tim - Parushev, Parush: Cesty pravoslavné teologie ve 20. století na Západ. Brno 2012, s. 220. 
Léon Bloy) a neotřelou analýzou „ruské duše“, která je dle něj vedena pravoslavnou vírou k odloučenosti od pozemských hodnot a inklinací k věčnému „Božímu království“. Oproti západní mentalitě si ruský člověk necení soukromého vlastnictví a spíše „....myslí ve svém nitru, že by pro něj bylo lépe vzíti mnišskou kutnu nebo státi se poutníkem. “34 Zásadní problém ruské mentality a důvod, proč je nutno revoluci považovat za „národní hřích“ a nikoli vnější import, dle Berdajeva ovšem spočívá v tom, že „Duše ruského člověka směřuje ke Království Božímu, ale ustupuje snadno pokušením, padělkům a ilusím, snadno upadá do moci království temnot." ${ }^{35}$

O systematičtější uchopení Berdajevova myšlení se pokusil zejména Dominik Pecka (1895-1981), kněz náležející k duchovní obnově českého katolicismu ve 30. letech, jejíž součástí byl i intelektuální apoštolát ve studentském prostředí, který rozvíjel společně s olomouckými dominikány. Pecka se pokoušel ve svých esejích v Akordu a revue Na hlu$b i n u^{36}$ přibližit českému prostředí různé inspirativní osobnosti z oblasti filozofie i teologie a jednou z nich byl právě Nikolaj Berdajev, který ho zaujal důrazem na svobodu člověka a christologicky orientovanou antropologií.

Pecka Berdajevovo myšlení shrnuje v odkazu k podstatnému principu dějin, jímž je boholidství: „Berdjajevovi je Kristus absolutním člověkem, věčným Bohočlověkem. Nám západním křestanům znamená Bohočlověk spíše jen dějinnou ideu. Kristus počíná pro nás existovati Vtělením, jenž se událo v čase. Berdjajevovi je Kristus Bohočlověkem od věčnosti. Lidská přirozenost existuje od věčnosti v Bohočlověku. Člověčenstvím Kristovým je celý kosmos pohřížen v Boha. Jinými slovy: člověk je středem vesmíru. [...] Kristus je Berdjajevovi posledním tajemstvím kosmu. [...] Antropologie se rodí z christologie, smysl člověka je v Kristu. “" ${ }^{37}$ Vztah člověka k Bohu je dán svobodou člověka, přičemž tajemství svobody dále vrcholí v tajemství kříže: „Syn Boží v podobě ukřižovaného otroka nenutí nikoho, aby ho uznal za Syna Božího. Ukřižovaný se obrací k svobodě lidského ducha." ${ }^{38}$ Peckovi také imponovala Berdajevova víra v univerzální Církev, v níž „bije jedno srdce“, ${ }^{39}$ nemohl však sdílet jeho poněkud odtažitý vztah k církevní autoritě. I když by se daly uvést mnohé další momenty, kterými zůstával Berdajev nejen v katolickém prostředí oslovující, například jeho analýza marxismu, skončeme své úvahy nad jeho dílem alespoň konstatováním, že se stal důležitým varovným hlasem střední i západní Evropě o zhoubnosti bolševismu a marxistického myšlení, bohužel oslyšeným. ${ }^{40}$

34 Tamtéž, s. 84.

35 Tamtéž, s. 85.

36 Vyšlo také souhrnně: Pecka, Dominik: Moderni člověk a křest'anství. Praha 1948, s. 237-267.

37 Tamtéž, s. 264-265.

38 Tamtéž, s. 242.

39 Tamtéž, s. 256.

40 Srov. Putna, Martin C. - Zadražilová, Miluše: Rusko mimo Rusko. Dějiny a kultura ruské emigrace 1917-1991. 1. díl. Brno 1993, s. 63. 


\section{Závěr}

Na závěr se pokusíme shrnout, v čem spočívají specifika recepce pravoslavných filozofů a teologů v českém katolickém prostředí ve 20. až 40. letech 20. století.

V prvé řadě šlo o úsilí vypořádat se s osobnostmi, které projevily touhu po sjednocení se západním křestanstvím a v případě Čaadajeva a Solovjova ji dokonce neváhaly označit za podstatný úkol ruského národa. Rezonovaly i úvahy zmíněných osobností o povaze ruského pravoslaví a ruské mentality i jejich chápání podstaty církve - to ostatně navazovalo i na starší unionistické tendence, které byly sice do jisté míry zaměřeny vzhledem k pravoslaví misijně, na druhé straně představovaly opravdový zájem o země i kulturu ortodoxního východu. Stranou ovšem nemůže zůstat ani souznění české katolické inteligence s kritikou „úpadkových jevů“ moderního světa, přítomnou v dílech ruských autorů. Negativně chápaný vývoj moderního světa a jeho problémů byl motivací zájmu a pokusů o sblížení. Tento fenomén by se snad dal označit jako „negativní ekumenismus“, který na druhé straně nevylučoval i pozitivní ocenění filozofických a literárních hodnot u pravoslavných myslitelů. Navíc, jakkoli byl katolicismus té doby velmi doktrinálně zpevněn a připomínal ideologicky dobře vystavěnou pevnost, pootevření oken do pravoslavného světa znamenalo počátky významné proměny, k níž došlo o několik desetiletí později, tj. v 60. letech 20. století.

V neposlední řadě byl součástí popsané recepce i zájem o náboženské či teologické zhodnocení vývoje v Rusku po roce 1917 a snaha o poznání obtížné situace pravoslavné církve v sovětské říši, kdy se ve středu pozornosti ocitaly zejména pohnuté životní osudy patriarchy Tichona, př́iběhy ruských mučedníků, peripetie omezování svobody ruské církve, ztráta církevního majetku i bolestná zkušenost kolaborace a napětí, jež revoluční vývoj v pravoslavné církvi vyvolával. Pravoslavný ruský svět byl českými katolíky obdivován nepochybně i kvůli svému silnému vlasteneckému cítění, které sice bylo v katolickém prostředí přítomno, bylo ovšem ostatními společenskými vrstvami zpochybřováno.

Můžeme konstatovat, že při vědomí uvedených specifik zůstává interpretace a překlady ruských autorů v rámci českého katolického milieu významným prvkem celkové kulturní produkce, na který se mohlo navázat i po roce 1989. Př́íkladem této kontinuity může být Centrum Alleti Velehrad - Roma sídlící v Olomouci, které institucionálně i svými vydavatelskými počiny v mnohém navazuje na katolické snahy o poznání ruské pravoslavné kultury. 


\section{A Czech Catholic View of Orthodox Philosophy and Theology from the 1920 s to the 1940 s}

In this article the authors examined the reception of works by Russian philosophers, theologians and writers who featured in Catholic-oriented journals published in Czechoslovakia in the first half of the 20th century. A total of five authors were selected (Piotr Y. Chaadayev, Nikolai V. Gogol, Fyodor M. Dostoyevsky, Vladimir S. Soloviev, Nikolai A. Berdyaev), whom they used as the basis to show what important Czech Catholic writers took from their works, what they translated and in what manner they were interpreted. The paper attempts to describe the key elements from Russian culture which were important for a Czech Catholic community emerging from the older unionist tradition, but at the same time was interested in the new philosophical, theological and cultural upheavals connected primarily with post-1917 Russian emigration. The translations and cultural contacts which have developed since 1989 might be seen as being related to these interpretations from the first half of the 20th century. 
